\title{
X-ray fluorescence spectrometry (XRFS) analysis of aluminum cable types commonly used in electric power distribution
}

\author{
B. J. Kwaha and O. M. Durodola \\ Department of Physics, University of Jos, Nigeria
}

kwahab68@yahoo.com

\begin{abstract}
A comparative analysis of 5 different aluminum cable types tagged $J_{1}, J_{2}, J_{3}, J_{4}$ and $J_{5}$, from 5 different cable manufacturing companies was carried out using 2 different test methods namely- x-ray fluorescence spectrometry (XRFS) and resistivity test with the main objective of ascertaining why some cables of the same gauge fail under the same load levels. Purity levels, resistivity and conductivity checks were performed. Equal dimensions of 5 cable brands were sampled and ground to fine powder. The percentage purity of each sample was determined through XRFS test. One set of similar samples was subjected to resistivity test. XRFS result shows that $J_{1}$ had purity of $99.30 \%, J_{2}$, $99.10 \%, \mathrm{~J}_{3}, 98.50 \%, \mathrm{~J}_{4}, 99.20 \%$ and $\mathrm{J}_{5}, 98.80 \%$. The cable types also had resistivity and conductivity values respectively as for $\mathrm{J}_{1}\left[2.324 \times 10^{-9} \Omega \mathrm{m} \& 430.29 \times 10^{6}(\Omega \mathrm{m})^{-1}\right], \mathrm{J}_{2}\left[3.921 \times 10^{-9} \Omega \mathrm{m} \& 255.04 \times 10^{6}(\Omega \mathrm{m})^{-1}\right], \mathrm{J}_{3}\left[2.689 \times 10^{-9}\right.$ $\left.\Omega \mathrm{m} \& 371.89 \times 10^{6}(\Omega \mathrm{m})^{-1}\right], \mathrm{J}_{4}\left[2.614 \times 10^{-9} \Omega \mathrm{m} \& 382.56 \times 10^{6}(\Omega \mathrm{m})^{-1}\right]$, and $\mathrm{J}_{5}\left[2.890 \times 10^{-9} \Omega \mathrm{m} \& 346.60 \times 10^{6}(\Omega \mathrm{m})^{-1}\right]$. Comparing these values to the standard resistivity value of pure aluminum $\left[2.82 \times 10^{-8} \Omega \mathrm{m}\right]$ it would be seen that these results are in agreement with theoretically computed values. The XRFS test used in this research could be used to test the purity of aluminum before stretching into cables. It can also be used to determine the standard of aluminum products. The electrical resistivity test could be used to determine and set a standard resistivity and conductivity requirements to be met by different cable brands and types used in electric power distribution so as to curb the menace of cable failure and electric hazards.
\end{abstract}

Keywords: Qualitative analysis, aluminum, cable types.

\section{Introduction}

Aluminum is one of the most widely used metals for manufacturing different types of electrical cables. Its use as an option for electrical cables is on the increase. Although, reduced cost is the main incentive to the use of aluminum in cable making, other advantages are abound. Aluminum is one of the most economically viable metals and hence cables from it are cheaper than those of copper, their nearest competitor. Aluminum is the most abundant element on earth, after oxygen and silicon and makes up about $8 \%$ by weight of the earth's solid surface (Polmear, 1995). However, aluminum is too chemically reactive to occur in nature as a free metal, but mostly found in bauxite ore, $\mathrm{Al}_{2} \mathrm{O}_{3}$ combined in over 270 different minerals (Shakhashiri, 2007). Some desirable properties that make aluminum a suitable material for electrical cables and wires are its light weight, high electrical conductivity, high ductility, high strength, high resistance to corrosion and low cost. Aluminum is non-magnetic in nature (Elmsley, 2001; Tipler, 2004) and can be easily machined and recycled. Aluminum is an industrial metal produced commercially from bauxite by electrolysis with purity ranging from 99\%-99.9\% (Higgins, 1971). Pure aluminum metal is soft, but it is strengthened by alloying with copper, magnesium, silicon or manganese before it can be used (Higgins, 1971). When aluminum nears its melting point, it becomes "hot short" and crumbles easily.

This paper aims at comparing and assessing different brands of aluminum cables (wires) from various manufacturing companies to determine which are best for domestic electrification as chemical analysis and analyses of electrical properties will be carried out on each brand of cables (wires) to determine their constituent substances and impurity concentration cum electrical conductivity and resistivity.

Theoretical background

Chemical analysis: X-ray fluorescence spectrometry (XRFS)

XRFS is one of the most widely used methods for analytical techniques in industries today. The machine used consists of a high voltage source which powers the $x$-ray tube. The $x$-ray from the tube irradiates the milled sample generating secondary fluorescence which corresponds to the characteristic of each element in the sample. These characteristic $x$-rays are separated by spectrometer into individual wavelengths and energies and measured by a detector. The method is nondestructive and is used to identify and determine concentration of elements present in solids, liquids or powdered samples. XRFS can be applied over a wide range of concentration from $1 \mathrm{ppm}$ to $100 \%$ (Larson, 2008). XRFS is also capable of measuring all elements from beryllium $(\mathrm{Be})$ to uranium $(\mathrm{U})$. XRFS can be applied in industries and research because of its ability to give accurate and reproducible analysis at very high speed. Samples for XRFS analysis should be presented to the spectrometer in a homogenous reproducible form. Metal samples must be milled or ground to give a flat surface. However, substances that undergo phase transitions may not be analyzed on this machine.
Research article

CIndian Society for Education and Environment (iSee)
"Quality analysis of aluminum cable" http://www.indjst.org
Kwaha \& Durodola Indian J.Sci.Technol. 


\section{Determination of electrical properties}

Electrical properties of cables (resistance \& resistivity) are determined using the meter bridge set up shown in Fig.1. The unknown resistance $R_{1}$, of the length of wire $A B$ is given by equation (1).

$$
\begin{aligned}
& \frac{R_{1}}{R_{2}}=\frac{L}{100-L} \\
& R_{1}=\frac{L R_{2}}{100-L}
\end{aligned}
$$

The slope of a graph of $R$ against $L$ is used to determine the resistivity of the samples with equation (2), where $d$ is the measured diameter of cable wire $\rho=\Pi(d / 2)^{2} x$ slope

Table 1. General properties of aluminum (Higgins, 1971; Allen,

\begin{tabular}{|c|c|}
\hline \multicolumn{2}{|c|}{ 2009) } \\
\hline Symbol, number & $\mathrm{A} 1,12$ \\
\hline Group period, block & $12,3, p$ \\
\hline Appearance & Grey \\
\hline Standard atomic weight & $26,9815386 \mathrm{~g} / \mathrm{mol}$ \\
\hline Electron configuration & $I s^{2} 2 s^{2} 2 p^{6} 3 s^{2} 3 p^{!}$ \\
\hline Electron per shell & $2,8,3$ \\
\hline Magnetic ordering & Paramagnetic \\
\hline Electrical resistivity & (at $20^{\circ} \mathrm{C}$ ) $28.1 \Omega / \mathrm{m}$ \\
\hline Thermal conductivity & $\left(\right.$ at $\left.25^{\circ} \mathrm{C}\right) 23.1 \mathrm{Nm} \cdot \mathrm{m}^{-1} \mathrm{k}^{-1}$ \\
\hline Thermal expansion & (at $300 \mathrm{k}) 237 \mathrm{~W} \cdot \mathrm{m}^{-1} \mathrm{k}^{-1}$ \\
\hline Speed of sound (thin rod) & $\begin{array}{l}\text { Groom temperature (rolled) } \\
500 \mathrm{~m} / \mathrm{s}\end{array}$ \\
\hline Young's modulus & 70Gpa \\
\hline Shear modulus & 26Gpa \\
\hline Bulk modulus & 76Gpa \\
\hline Poisson ration & 0.35 \\
\hline Mohs hardness & 2.75 \\
\hline Vickers hardness & 167Mpa \\
\hline Brinell hardness & 245.Mpa \\
\hline Phase & Solid \\
\hline $\begin{array}{l}\text { Density (near room } \\
\text { temperature) }\end{array}$ & $2.70 \mathrm{~g} / \mathrm{cm}^{3}$ \\
\hline Liquid density at melting point & $2.375 \mathrm{~g} / \mathrm{cm}^{-3}$ \\
\hline Melting point & $933.47 \mathrm{k}\left(660.32^{\circ} \mathrm{C}, 1220.58^{\circ} \mathrm{F}\right)$ \\
\hline Boiling point & $2792 \mathrm{k}\left(2519^{\circ} \mathrm{C}, 4566^{\circ} \mathrm{F}\right)$ \\
\hline Heat of fusion & $10.7 \mathrm{~J} / \mathrm{mol}$ \\
\hline Heat of vaporization & $294.0 \mathrm{~kJ} / \mathrm{mol}$ \\
\hline Specific heat capacity & $\left(25^{\circ} \mathrm{C}\right) 24.200 \mathrm{~J} / \mathrm{mol} . \mathrm{k}$. \\
\hline Crystal structure & $\begin{array}{l}\text { Face centered cubic } \\
(0.40494 \mathrm{~nm}) .\end{array}$ \\
\hline Electro-negativity & 1.61 (Pauling scale) \\
\hline Ionization energies & $\begin{array}{l}1^{\text {st }}: 577.5 \mathrm{k} \mathrm{J} / \mathrm{mol} ; 2^{\text {ndd }}: 1816.7 \mathrm{k} \\
\mathrm{J} / \mathrm{mol} ; \quad 3^{\text {rd }}: 2744.8 \mathrm{k} \mathrm{J} / \mathrm{mol}\end{array}$ \\
\hline Atomic radius & 125 picometer $(\mathrm{pm})$ \\
\hline Covalent radius & 118 picometer $(\mathrm{pm})$ \\
\hline
\end{tabular}
1983; Dieter, 1988; Polmear, 1995; Griffiths, 1998; Wikipedia,

\section{Materials and methods}

Five samples of aluminum cables available in Nigerian market were collected from various companies and tested:
Vol. 4 No. 5 (May 2011)

ISSN: 0974- 6846

Fig. 1. Meter bridge setup.

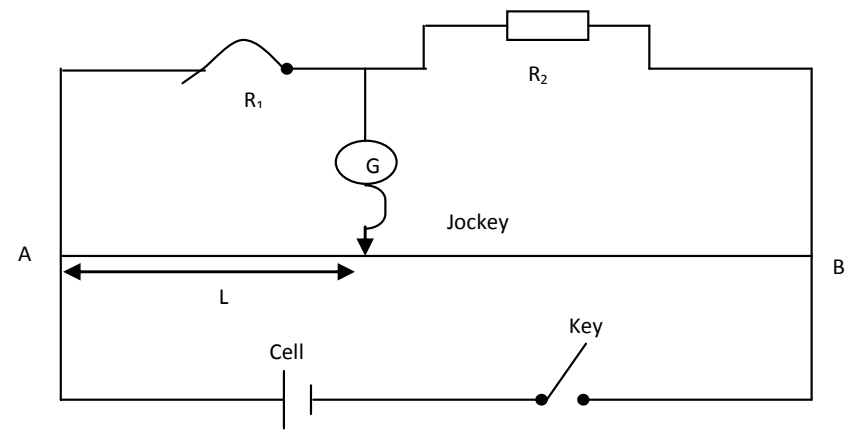

Sample $J_{1}$ : Alind aluminum cable, Sample $J_{2}$ : Curtix aluminum cable, Sample $J_{3}$ : Moonlight aluminum cable, Sample $J_{4}$ : Sunrise aluminum cable and Sample $J_{5}$ : Newcon aluminum cable.

\section{Chemical analysis}

The samples were ground and sieved to $75 \mu \mathrm{m}$ particle size. $4 \mathrm{~g}$ of the sieved sample was intimately mixed with $1 \mathrm{~g}$ of lithium tetra-borate binder $\left(\mathrm{Li}_{2} \mathrm{~B}_{4} \mathrm{O}_{7}\right)$ and pressed in a mould under a pressure of $10-15$ tons $/ \mathrm{in}^{2}$ to a pellet. The pressed pellets were dried at $110^{\circ} \mathrm{C}$ for 30 $\min$ in an oven to get rid of absorbed moisture. The spectrometer was switched on and allowed to warm up and stabilize the optics and x-ray tube. It was then calibrated to determine the expected element present in the samples. Samples were run using the prepared calibration programs and the elements concentrations present in the samples were calculated and displayed after applying automatic statistics to the results by the spectrometer. These results are shown in Tables 2 and 3. Electrical analysis

1. The meter-bridge was set up to determine unknown resistance for each sample of wire $\left(J_{1}\right.$ to $\left.J_{5}\right)$ for varying lengths of $10,20,30,40$ and $50 \mathrm{~cm}$ as shown in Table 4.

2. A graph of $R$ against $L$ was plotted for each sample and each slope was obtained using spreadsheet.

3. Resistivity and conductivity values of the samples were calculated and shown in Table 6.

\section{Result and analysis}

Results of chemical analysis using the $x$-ray fluorescence spectrometry are shown in Tables 2 and 3 , while results of electrical analysis to determine resistivity and conductivity of sampled wires using meter-bridge are shown in Tables 4 and 6 respectively.

\section{Discussion}

The paper compared and assessed 5 different aluminum cables from different manufacturing industries namely, Alind, Curtix, Moonlight, Sunrise and Newconused in domestic electrification in Nigeria with a bid to assess the validity of failure rate usually associated to the use of aluminum cables. A common phenomenon is that 
Table 2. Data from spectroscopy.

\begin{tabular}{|c|c|c|c|c|c|c|c|c|c|c|}
\hline \multirow{4}{*}{$\begin{array}{c}\text { Sample } \\
J_{1}\end{array}$} & $\% \mathrm{Al}$ & $\% \mathrm{P}$ & $\%$ S & $\% \mathrm{Si}$ & $\% \mathrm{~K}$ & $\% \mathrm{Ca}$ & $\% \mathrm{Ti}$ & $\% \mathrm{~V}$ & $\% \mathrm{Cr}$ & $\% \mathrm{Mn}$ \\
\hline & 99.33 & 0.08 & 0.09 & 0.10 & ND & 0.10 & 0.006 & ND & 0.004 & 0.01 \\
\hline & $\% \mathrm{Fe}$ & $\% \mathrm{Ni}$ & $\% \mathrm{Cu}$ & $\%$ Zn & $\% \mathrm{Se}$ & $\% \mathrm{Ba}$ & $\% \mathrm{As}$ & $\% \mathrm{Ga}$ & $\% \mathrm{~Pb}$ & \\
\hline & 0.15 & 0.003 & 0.01 & 0.01 & ND & 0.03 & ND & 0.008 & ND & \\
\hline \multirow{4}{*}{$\begin{array}{c}\text { Sample } \\
\mathrm{J}_{2}\end{array}$} & $\% \mathrm{Al}$ & $\% \mathrm{P}$ & $\% \mathrm{~S}$ & $\% \mathrm{Si}$ & $\% \mathrm{~K}$ & $\% \mathrm{Ca}$ & $\% \mathrm{Ti}$ & $\% \vee V$ & $\% \mathrm{Cr}$ & $\% \mathrm{Mn}$ \\
\hline & 99.10 & 0.12 & ND & 0.26 & ND & 0.19 & 0.01 & ND & 0.01 & 0.007 \\
\hline & $\% \mathrm{Fe}$ & $\% \mathrm{Ni}$ & $\% \mathrm{Cu}$ & $\% \mathrm{Zn}$ & $\% \mathrm{Se}$ & $\% \mathrm{Ba}$ & $\% \mathrm{As}$ & $\%$ Ga & $\% \mathrm{~Pb}$ & \\
\hline & 0.14 & 0.002 & 0.03 & 0.01 & ND & ND & 0.002 & 0.02 & ND & \\
\hline \multirow{4}{*}{$\underset{J_{3}}{\text { Sample }}$} & $\% \mathrm{Al}$ & $\% \mathrm{P}$ & $\%$ S & $\% \mathrm{Si}$ & $\% \mathrm{~K}$ & $\% \mathrm{Ca}$ & $\% \mathrm{Ti}$ & $\% \mathrm{~V}$ & $\% \mathrm{Cr}$ & $\% \mathrm{Mn}$ \\
\hline & 98.50 & 0.34 & ND & 0.50 & ND & 0.28 & ND & 0.01 & 0.008 & 0.01 \\
\hline & $\% \mathrm{Fe}$ & $\% \mathrm{Ni}$ & $\% \mathrm{Cu}$ & $\% \mathrm{Zn}$ & $\% \mathrm{Se}$ & $\% \mathrm{Ba}$ & $\% \mathrm{As}$ & $\% \mathrm{Ga}$ & $\% \mathrm{~Pb}$ & \\
\hline & 0.24 & 0.01 & 0.04 & 0.004 & 0.004 & ND & 0.01 & 0.01 & 0.03 & \\
\hline \multirow{4}{*}{$\underset{J_{4}}{\text { Sample }}$} & $\% \mathrm{Al}$ & $\% \mathrm{P}$ & $\% \mathrm{~S}$ & $\% \mathrm{Si}$ & $\% \mathrm{~K}$ & $\% \mathrm{Ca}$ & $\% \mathrm{Ti}$ & $\% \mathrm{~V}$ & $\% \mathrm{Cr}$ & $\% \mathrm{Mn}$ \\
\hline & 99.20 & 0.11 & 0.06 & 0.11 & 0.03 & 0.13 & 0.01 & ND & 0.005 & 0.01 \\
\hline & $\% \mathrm{Fe}$ & $\% \mathrm{Ni}$ & $\% \mathrm{Cu}$ & $\% \mathrm{Zn}$ & $\% \mathrm{Se}$ & $\% \mathrm{Ba}$ & $\% \mathrm{As}$ & $\% \mathrm{Ga}$ & $\% \mathrm{~Pb}$ & \\
\hline & 0.21 & 0.004 & 0.02 & 0.006 & ND & 0.02 & ND & 0.007 & ND. & \\
\hline \multirow{4}{*}{$\underset{J_{5}}{\text { Sample }}$} & $\% \mathrm{Al}$ & $\% \mathrm{P}$ & $\% \mathrm{~S}$ & $\% \mathrm{Si}$ & $\% \mathrm{~K}$ & $\% \mathrm{Ca}$ & $\% \mathrm{Ti}$ & $\% \mathrm{~V}$ & $\% \mathrm{Cr}$ & $\% \mathrm{Mn}$ \\
\hline & 98.80 & 0.13 & 0.10 & 0.08 & 0.04 & 0.31 & 0.009 & ND & 0.006 & $\begin{array}{l}0.01 \\
\end{array}$ \\
\hline & $\% \mathrm{Fe}$ & $\% \mathrm{Ni}$ & $\% \mathrm{Cu}$ & $\% \mathrm{Zn}$ & $\% \mathrm{Se}$ & $\% \mathrm{Ba}$ & $\% \mathrm{As}$ & $\% \mathrm{Ga}$ & $\% \mathrm{~Pb}$ & \\
\hline & 0.25 & 0.007 & 0.01 & 0.02 & ND & 0.33 & ND & 0.006 & ND & \\
\hline
\end{tabular}

showed the chemical constituents of the aluminum cables to include; Phosphorus (P), Sulphur (S), Silicon (Si), Potassium (K), Selenium (Se), Vanadium (V), Calcium (Ca), Titanium (Ti), Chromium (Cr), Manganese (Mn), Iron (Fe), Nickel (Ni), copper $(\mathrm{Cu})$, Zinc $(\mathrm{Zn})$, Barium (Ba), Arsenic (As) Gallium $(\mathrm{Ga})$ and Lead $(\mathrm{Pb})$ but not all of these are contained in all the cable samples.

Sample J1 does not contain As, K, Se, V, Pb; Sample $\mathrm{J}_{2}$ does not

Table 3. Percentage chemical composition of samples.

\begin{tabular}{|c|c|c|c|c|c|}
\hline \multirow{2}{*}{$\begin{array}{c}\text { Chemical } \\
\text { elements }\end{array}$} & $\begin{array}{c}\text { Sample } \\
\mathrm{J}_{1}\end{array}$ & $\begin{array}{c}\text { Sample } \\
\mathrm{J}_{2}\end{array}$ & $\begin{array}{c}\text { Sample } \\
\mathrm{J}_{3}\end{array}$ & $\begin{array}{c}\text { Sample } \\
\mathrm{J}_{4}\end{array}$ & $\begin{array}{c}\text { Sample } \\
\mathrm{J}_{5}\end{array}$ \\
\hline $\mathrm{Al}$ & 99.33 & 99.10 & 98.50 & 99.20 & 98.80 \\
\hline $\mathrm{P}$ & 0.08 & 0.12 & 0.34 & 0.11 & 0.13 \\
\hline $\mathrm{S}$ & 0.09 & $\mathrm{ND}$ & $\mathrm{ND}$ & 0.06 & 0.10 \\
\hline $\mathrm{Si}$ & 0.10 & 0.26 & 0.50 & 0.11 & 0.08 \\
\hline $\mathrm{K}$ & $\mathrm{ND}$ & $\mathrm{ND}$ & $\mathrm{ND}$ & 0.03 & 0.04 \\
\hline $\mathrm{Ca}$ & 0.10 & 0.19 & 0.28 & 0.13 & 0.31 \\
\hline $\mathrm{Ti}$ & 0.006 & 0.01 & $\mathrm{ND}$ & 0.01 & 0.009 \\
\hline $\mathrm{V}$ & $\mathrm{ND}$ & $\mathrm{ND}$ & 0.01 & $\mathrm{ND}$ & $\mathrm{ND}$ \\
\hline $\mathrm{Cr}$ & 0.004 & 0.01 & 0.008 & 0.005 & 0.006 \\
\hline $\mathrm{Mn}$ & 0.01 & 0.007 & 0.01 & 0.01 & 0.01 \\
\hline $\mathrm{Fe}$ & 0.15 & 0.14 & 0.24 & 0.21 & 0.25 \\
\hline $\mathrm{Ni}$ & 0.003 & 0.002 & 0.01 & 0.004 & 0.007 \\
\hline $\mathrm{Cu}$ & 0.01 & 0.03 & 0.04 & 0.02 & 0.01 \\
\hline $\mathrm{Zn}$ & 0.01 & 0.01 & 0.004 & 0.006 & 0.02 \\
\hline $\mathrm{Se}$ & $\mathrm{ND}$ & $\mathrm{ND}$ & 0.004 & $\mathrm{ND}$ & $\mathrm{ND}$ \\
\hline $\mathrm{Ba}$ & 0.03 & $\mathrm{ND}$ & $\mathrm{ND}$ & 0.02 & 0.33 \\
\hline $\mathrm{As}$ & $\mathrm{ND}$ & 0.002 & 0.01 & $\mathrm{ND}$ & $\mathrm{ND}$ \\
\hline $\mathrm{Ga}$ & 0.008 & 0.02 & 0.01 & 0.007 & 0.006 \\
\hline $\mathrm{Pb}$ & $\mathrm{ND}$ & $\mathrm{ND}$ & 0.03 & $\mathrm{ND}$ & $\mathrm{ND}$ \\
\hline & & $\mathrm{ND}=\mathrm{Not}$ detectable & \\
& & \multicolumn{3}{c}{} \\
\hline
\end{tabular}

of cable failure leading to cables melting under loads it is expected to handle conveniently.

\section{Summary of chemical analysis}

The percentage chemical composition of each cable was obtained chemically using the XRFS test at national metallurgical development centre (NMDC), Jos. The chemical analysis; showed that $J_{1}$ has the highest percentage purity of aluminum- $99.30 \%$. After which is $\mathrm{J}_{4^{-}}$ $99.20 \%, J_{2}-99.10 \%, J_{5}-98.80 \%$ and $J_{3}-98.50 \%$. Also $J_{1}$ has the highest percentage of copper which improves its strength and conductivity (Davis, 1999). The results also Research article (C)Indian Society for Education and Environment (iSee)
Table 4. Measured values of balance points \& unknown

\begin{tabular}{|c|c|c|c|}
\hline \multicolumn{4}{|c|}{ resistance of sampled wires. } \\
\hline Sample & $\begin{array}{l}\text { Length, } \\
\mathrm{Y}(\mathrm{CM})\end{array}$ & $\begin{array}{l}\text { Balance } \\
\text { point, } L\end{array}$ & $\begin{array}{c}\text { Unknown } \\
\text { resistance, } \mathrm{R}_{1} \\
R_{1}=\frac{L x R_{2}}{100-L} \\
(\Omega)\end{array}$ \\
\hline \multirow{5}{*}{$\mathrm{J}_{1}$} & 10.0 & 5.76 & 0.122 \\
\hline & 20.0 & 6.10 & 0.130 \\
\hline & 30.0 & 6.50 & 0.140 \\
\hline & 40.0 & 7.00 & 0.150 \\
\hline & 50.0 & 7.40 & 0.160 \\
\hline \multirow{5}{*}{$\mathrm{J}_{2}$} & 10.0 & 4.70 & 0.099 \\
\hline & 20.0 & 5.40 & 0.144 \\
\hline & 30.0 & 6.30 & 0.135 \\
\hline & 40.0 & 7.30 & 0.158 \\
\hline & 50.0 & 8.30 & 0.181 \\
\hline \multirow{5}{*}{$\mathrm{J}_{3}$} & 10.0 & 12.70 & 0.291 \\
\hline & 20.0 & 13.20 & 0.304 \\
\hline & 30.0 & 14.90 & 0.350 \\
\hline & 40.0 & 15.20 & 0.360 \\
\hline & 50.0 & 16.10 & 0.386 \\
\hline \multirow{5}{*}{$\mathrm{J}_{4}$} & 10.0 & 5.50 & 0.116 \\
\hline & 20.0 & 5.80 & 0.123 \\
\hline & 30.0 & 6.20 & 0.132 \\
\hline & 40.0 & 6.80 & 0.146 \\
\hline & 50.0 & 7.50 & 0.162 \\
\hline \multirow{5}{*}{$\mathrm{J}_{5}$} & 10.0 & 6.20 & 0.132 \\
\hline & 20.0 & 7.10 & 0.163 \\
\hline & 30.0 & 7.80 & 0.169 \\
\hline & 40.0 & 8.60 & 0.188 \\
\hline & 50.0 & 9.50 & 0.210 \\
\hline
\end{tabular}

contain S, K, V, Se, Ba, Pb; Sample J3 does not contain $\mathrm{S}, \mathrm{K}, \mathrm{Ti}, \mathrm{Ba}$; Sample J4 does not constitute V, Se, As, Pb and Sample J5 does not constitute V, Se, As, Pb. According to Davis (1999) the constituent elements can 
Vol. 4 No. 5 (May 2011)

ISSN: 0974- 6846
Table 5. Values of length \& unknown resistance for various samples (Used for spread sheet).

\begin{tabular}{|c|c|c|c|c|c|}
\hline \multirow{2}{*}{$\begin{array}{c}\text { Length } \\
(\mathrm{cm})\end{array}$} & \multicolumn{5}{|c|}{ Unknown Resistance, $\mathrm{R}_{1}(\Omega)$} \\
\cline { 2 - 6 } & $\begin{array}{c}\text { Sample } \\
\mathrm{J}_{1}\end{array}$ & $\begin{array}{c}\text { Sample } \\
\mathrm{J}_{2}\end{array}$ & $\begin{array}{c}\text { Sample } \\
\mathrm{J}_{3}\end{array}$ & $\begin{array}{c}\text { Sample } \\
\mathrm{J}_{4}\end{array}$ & $\begin{array}{c}\text { Sample } \\
\mathrm{J}_{5}\end{array}$ \\
\hline 10.0 & 0.122 & 0.099 & 0.291 & 0.116 & 0.132 \\
\hline 20.0 & 0.130 & 0.144 & 0.304 & 0.123 & 0.163 \\
\hline 30.0 & 0.140 & 0.135 & 0.350 & 0.132 & 0.169 \\
\hline 40.0 & 0.150 & 0.158 & 0.360 & 0.146 & 0.188 \\
\hline 50.0 & 0.160 & 0.181 & 0.386 & 0.162 & 0.210 \\
\hline
\end{tabular}

Table 6. Resistivity \& Conductivity Values of Sampled Wires.

\begin{tabular}{|c|c|c|c|c|}
\hline Sample & $\begin{array}{c}\text { Mean } \\
\text { resistance, } \\
\mathrm{R}(\Omega)\end{array}$ & $\begin{array}{c}\text { Resistivity } \rho \\
(\Omega \mathrm{m}) \\
\mathrm{n}(\mathrm{d} / 2)^{2} \times \text { slope }\end{array}$ & $\begin{array}{c}\text { Conductivity } \\
(\Omega \mathrm{m})^{-} \\
\sigma=1 / \rho\end{array}$ & $\begin{array}{c}\text { Standard } \\
\text { value of } \\
\text { resistivity } \\
(\Omega \mathrm{m})\end{array}$ \\
\hline $\mathrm{J}_{1}$ & 0.140 & $2.324 \times 10^{-9}$ & $430.29 \times 10^{6}$ & $2.82 \times 10^{-8}$ \\
\hline $\mathrm{J}_{2}$ & 0.137 & $3.921 \times 10^{-9}$ & $255.04 \times 10^{6}$ & $2.82 \times 10^{-8}$ \\
\hline $\mathrm{J}_{3}$ & 0.338 & $2.689 \times 10^{-9}$ & $371.89 \times 10^{6}$ & $2.82 \times 10^{-8}$ \\
\hline $\mathrm{J}_{4}$ & 0.136 & $2.614 \times 10^{-9}$ & $382.56 \times 10^{6}$ & $2.82 \times 10^{-8}$ \\
\hline $\mathrm{J}_{5}$ & 0.170 & $2.890 \times 10^{-9}$ & $346.60 \times 10^{6}$ & $2.82 \times 10^{-8}$ \\
\hline
\end{tabular}

\section{Conclusion}

The results from the chemical analysis and the electrical test show that sample $J_{1}$ is the best cable to be used in electrical domestic electrification. Having the highest percentage of aluminum $(99.30 \%)$ it retains most of the properties that makes aluminum an excellent conductor. It also contains the highest percentage of copper $(0.01 \%)$ which is one of the most important alloy in aluminum cables for improved strength and conductivity. Hence, it can be concluded that $J_{1}$ meets up to the standard to be used for domestic electrification. This is followed by $J_{4}, J_{3}, J_{5}$ and $J_{2}$. Also considering the results from the chemical analysis in Tables 2 and 3 , $J_{1}$ is also the cable with the highest percentage purity of aluminum and also the highest percentage of copper. It can be concluded therefore, that $J_{1}$ is the best aluminum cable to be used in domestic electrification.

We suggest that further work should be carried out on other aluminum cables to determine the source of impurities in cables and more extensive research their effects on cable performance. Furthermore, research should be intensified to upgrade the aluminum cables and reduce incidences of electrical fire outbreak in aluminum cables.

cables:

1. Impurity alloys like $\mathrm{Cu}, \mathrm{Zn} \mathrm{Mn}, \mathrm{Fe}, \mathrm{Cr}, \mathrm{Ni}, \mathrm{As}$ and $\mathrm{P}$ increase the strength and hardness of the cable, while $\mathrm{Cu}$, Se, $\mathrm{Ti}, \mathrm{V}$, and $\mathrm{Cr}$ improve the electrical conductivity in cables; and Silicon lowers the melting point of the cable.

2. $\mathrm{Mn}, \mathrm{P}, \mathrm{Ti}, \mathrm{Ni}$ and $\mathrm{Pb}$ improve the cables' non-corrosive nature and increase the electrical contact properties for high yield point and sufficient flexibility for use under difficult conditions in unfavourable atmosphere.

3. Sulphur and manganese should be in negligible quantity because they make the cables brittle.

4. Iron reduces the ductility, while gallium increases the electrical resistivity of the cables thereby reducing its conductivity.

\section{Summary of electrical analysis}

Sample $J_{1}$ has a low resistivity, $\rho$ value of $2.324 \times 10^{9}$ $\Omega \mathrm{m}$ and a high conductivity value of $430.29 \times 10^{6}(\Omega \mathrm{m})^{-1}$. It is followed by $J_{4}$ with resistivity value of $2.614 \times 10^{-8} \Omega$ $\mathrm{m}$ and conductivity of $382.53 \times 10^{6}(\Omega \mathrm{m})^{-1}$. It is closely matched by sample $J_{3}$ with a resistivity value of $2.689 \mathrm{x}$ $10^{-9} \Omega \mathrm{m}$ and conductivity value of $374.89 \times 10^{6}(\Omega \mathrm{m})^{-1}$. The next is $J_{5}$ which has resistivity and conductivity values of $2.890 \times 10^{-9} \Omega \mathrm{m}$ and $346.046 \times 10^{6}(\Omega \mathrm{m})^{-1}$ respectively and sample $J_{2}$ with a high resistivity and a low conductivity of $3.921 \times 10^{-9} \Omega \mathrm{m}$ and $255.036 \times 10^{6}$ $(\Omega \mathrm{m})^{-1}$ respectively. Judging from the electrical test $J_{1}$ has the lowest resistivity and highest conductivity compared to the other cables, and so it is the best as a conductor cable.

\section{References}

1. Allen DK (1983) Metallurgy theory and practices. American Technical Society, Chicago, U.S.A.

2. Davis JR (1999) Corrosion of aluminum and aluminum alloys. ASM International.

3. Dieter GE (1988) Mechanical metallurgy, McGraw Hill, NY

4. John E (2001) Aluminum, nature's building blocks. An S-Z guide to the elements, Oxford University Press, Oxford.

5. Higgins RA (1971) Engineering metallurgy ( $3^{\text {rd }}$ edn.), English Universities Press, London, U.K

6. Larson BF (2008) Centre for non-destructive evaluation. Lowa State University U.S.A. www.ndt.ed/org.

7. Polmear IJ (1995) Light alloys: Metallurgy of the light metals. Arnolds, USA. $2^{\text {nd }}$ Edition.

8. Shakhashiri BZ (2007) Chemical analysis of the weak Aluminum. McGraw Hill, NY.

9. Tipler P (2004) Physics for scientists and engineers: Electricity, magnetism, light and elementary modern Physics. McGraw Hill, NY ( $5^{\text {th }}$ Edition.).

10. Wikipedia (2009) www.wikipedia/allelectricalproducts. com
Research article

COIndian Society for Education and Environment (iSee)
"Quality analysis of aluminum cable" http://www.indjst.org
Kwaha \& Durodola Indian J.Sci.Technol. 